\title{
JAN III SOBIESKI WOBEC CERKWI PRAWOSŁAWNEJ I UNICKIEJ
}

\author{
Dorota Wereda http://orcid.org/0000-0003-1084-2212 \\ Uniwersytet Przyrodniczo-Humanistyczny w Siedlcach
}

\section{ABSTRACT \\ JOHN III SOBIESKI TOWARDS THE ORTHODOX AND THE UNIATE CHURCHES}

John III Sobieski had to deal with the problem of conflicted religious denominations, i.e. the Eastern Churches: the Uniate Church and the Eastern Orthodox Church, which had been in conflict for almost 80 years. The King's actions were dependent on various aspects of international politics. Religious matters were an important part of shaping relations with Russia and the Cossacks and remained within the area of interest of the Holy See. Having established peace with Russia, the King left aside the concept of establishing an autocephalous Eastern Orthodox Church in the territory of the Polish-Lithuanian Commonwealth and adopted a strategy of expanding the union in the Eastern Orthodox Church dioceses by trying to convince individual hierarchs to this concept. For bishops the king nominated individuals who favoured the union and enjoyed trust among the Cossack community, but most of all, who were experienced officials and soldiers holding high esteem among local nobleman elites. The policy-making of John III Sobieski contributed to expanding the Catholic Kiev Metropolis of the Eastern Rite (united with Rome) over the Przemyśl, Lutsk and Lviv bishoprics. The aim of Sobieski's policies related to religious denominations was to lead to a change in religious attitudes by way of people identifying themselves with the state's interests.

Keywords: modern history, Uniate Church in the Polish-Lithuanian Commonwealth, the Uniate Kyiv ecclesiastical province, John III Sobieski.

Słowa kluczowe: historia nowożytna, Kościół unicki w Rzeczypospolitej, kijowska metropolia unicka, Jan III Sobieski.

Jan III Sobieski po wstąpieniu na tron musiał zmierzyć się z rozwiązaniem kwestii wyznaniowych skonfliktowanych od niemal 80 lat Kościołów wschodnich: Cerkwi unickiej i Cerkwi prawosławnej. „Uspokojenie ludzi religii greckiej” było 
zobowiązaniem nałożonym na Sobieskiego w paktach konwentach podczas sejmu elekcyjnego ${ }^{1}$.

Sytuacja organizacyjna Kościołów wschodnich pozostawała złożona. Przez biskupów unickiej metropolii kijowskiej obsadzone były katedry w Chełmie, Pińsku, Połocku i Włodzimierzu oraz w Wilnie, dokąd po traktacie andruszowskim przeniesiono stolicę metropolii. W organizacji hierarchicznej Cerkwi prawosławnej po zajęciu Kijowa przez Rosję w eparchii metropolitalnej i metropolii ustaliła się podwójna władza: w granicach Rzeczypospolitej i w Rosji. Skomplikowaną sytuację Cerkwi prawosławnej w Rzeczypospolitej pogłębiała dezorganizacja spowodowana podwójnym wyborem metropolity: Antoniego Winnickiego, któremu podlegały eparchie przemyska, lwowska i łucka, i Józefa Nielubowicza Tukalskiego, który w 1668 roku uzyskał błogosławieństwo na metropolię od patriarchy carogrodzkiego (konstantynopolitańskiego) i jako legalny metropolita Ukrainy kozackiej do śmierci (2 listopada 1675 r.) przebywał w Czehryniu. Złożone stosunki hierarchiczne Cerkwi prawosławnej komplikowało powołanie w 1681 roku przez patriarchę carogrodzkiego odrębnej metropolii kamienieckiej z siedzibą w Kamieńcu, obejmującej obszar diecezji lwowskiej na okupowanym przez Portę Ottomańską Podolu. Kryzys organizacyjny pogłębiał konflikt o katedrę we Lwowie pomiędzy wyświęconym w 1668 roku przez metropolitę Antoniego Winnickiego Eustachym-Jeremiaszem Świstelnickim a wybranym przez szlachtę i duchowieństwo Janem (w stanie duchownym Józefem) Szumlańskim².

Sytuacja wyznaniowa w Rzeczypospolitej pozostawała w kręgu zainteresowania Stolicy Apostolskiej. Nuncjusz papieski w Warszawie Francesco Buonvisi wkrótce po elekcji przeprowadził z Janem III Sobieskim rozmowę w celu wypracowania stanowiska wobec Cerkwi prawosławnej i unickiej. Nuncjusz stał na stanowisku, że o pomyślności Rzeczypospolitej zdecyduje podporządkowanie prawosławnych papiestwu, i zasugerował utworzenie autokefalicznej Cerkwi prawosławnej na terytorium Rzeczypospolitej. Król uznał propozycje za dobre rozwiązanie ${ }^{3}$. Wdrożeniu tych koncepcji miała służyć konstytucja uchwalona na sejmie w 1676 roku, zakazująca prawosławnym utrzymywania kontaktów ze swym zwierzchnikiem, patriarchą carogrodzkim ${ }^{4}$. W uzasadnieniu odwoływano się do zapewnienia bezpieczeństwa państwa, rozumianego jako ochrona przed działalnością szpiegów Porty. Postanowienie to zyskało uznanie. Szlachta zgromadzona na sejmikach przed sejmem w 1677 roku nie domagała się jego zniesienia i uznała raczej prewencyjny charakter zakazus

1 Volumina Legum [dalej: VL], wyd. J. Ohryzko, t. V, Sankt Petersburg 1860, s. 140-141.

2 L. Bieńkowski, Organizacja Kościoła wschodniego w Polsce [w:] Kościót w Polsce, red. J. Kłoczowski, t. 2, Kraków 1968, s. 854-855; M. Andrusiak, Józef Szumlański. Pierwszy biskup unicki lwowski (1667-1708), Lwów 1934, s. 26-31; A. Gil, I. Skoczylas, Szumlański Jan (Iwan), w zakonie Józef [w:] Polski stownik biograficzny [dalej: PSB], t. XLIX, Warszawa-Kraków 2012, s. 343350 .

Litterae Nuntiorum Apostolicorum historiam Ucrainae illustrantes, vol. 12 (1670-1674), collegit, paravit, adnotavit editionemque curavit P. Athanasius, G. Welykyj, Romae 1968, s. 314-315.

4 VL, t. V, s. 150.

5 J. Wołoszyn, Problematyka wyznaniowa w praktyce parlamentarnej Rzeczypospolitej $w$ latach 1648-1696, Warszawa 2003, s. 248. 
Konsekwencją zakazu było osłabienie autonomii posiadających przywilej stauropigii prawosławnych bractw cerkiewnych, które zostały podporządkowane wyłącznej jurysdykcji biskupów ${ }^{6}$. Ograniczenie praw wyznawców prawosławia do kontaktów z patriarchą prowadziło do izolacji, ale również skierowało prawosławnych mieszkańców Rzeczypospolitej ku Rosji, czego król albo nie przewidział, albo uległ wizji dyplomacji Stolicy Apostolskiej, zmierzającej do rozszerzenia wpływów religijnych w prawosławnej Rosji.

Pod wpływem nowej koncepcji Stolicy Apostolskiej, wdrażanej przez przybyłego do Warszawy 24 grudnia 1675 roku kolejnego nuncjusza Franciszka Martellego, zmieniono taktykę. Rozszerzenie unii w prawosławnych diecezjach w Rzeczypospolitej miało nastąpić poprzez przekonanie do niej poszczególnych hierarchów. Pierwsza nominacja nie przyniosła oczekiwanych rezultatów. W 1676 roku przywilej na prawosławne biskupstwo białoruskie król wydał życzliwie odnoszącemu się do idei unii Teodozemu Wasilewiczowi. Biskup wbrew oczekiwaniom po objęciu diecezji nie zadeklarował przystąpienia do unii. W tej sytuacji, na skutek nacisków nuncjusza Martellego unieważniono przywilej królewski, ale nie podjęto prób fizycznego odebrania Wasilewiczowi katedry. Sędziwy hierarcha pozostał przy katedrze w Mohylewie do śmierci w $1678 \mathrm{roku}^{7}$.

W kolejnych decyzjach Jan III Sobieski, korzystając z przysługującego monarsze prawa patronatu (ius patronatus), wybrał metodę promowania na biskupów prawosławnych diecezji osób zaufanych, wywodzących się z najlepiej znanego mu środowiska wojskowego ${ }^{8}$. W sporze o katedrę we Lwowie wsparł J. Szumlańskiego, cieszącego się uznaniem szlachty syna rotmistrza królewskiego Eustachego Stanisława, wieloletniego kompana wypraw wojennych i doświadczonego polityka w sprawach prowadzonych pomiędzy Rzecząpospolitą a wojskiem zaporoskim9 ${ }^{9}$ Król promował Szumlańskiego do kolejnych godności cerkiewnych. W 1675 roku wykorzystując podeszły wiek metropolity Tukalskiego, mianował go, ignorując metropolitę A. Winnickiego, administratorem prawosławnej metropolii kijowskiej ${ }^{10}$. Zabieg ten miał pozyskać zaufanie społeczności prawobrzeżnej Ukrainy, a jednocześnie zahamować wpływy Rosji pretendującej do przejęcia protektoratu nad wyznawcami prawosławia

6 VL, t. V, s. 180; A. Mironowicz, Kościót prawosławny w dziejach dawnej Rzeczypospolitej, Białystok 2001, s. 221.

A. Mironowicz, Działalność nuncjusza Franciszka Martellego w Rzeczypospolitej w latach 1675-1681 [w:] Nuncjatura Apostolska w Rzeczypospolitej, red. T. Chynczewska-Hennel, K. Wiszowata-Walczak, Białystok 2012, s. 329-331.

8 Polityka personalna Sobieskiego wobec biskupów unickich została przedstawiona w odrębnym opracowaniu: D. Wereda, Polityka Jana III Sobieskiego wobec hierarchów cerkiewnych [w:] Społeczeństwo polskie i wojsko. Studia i materiaty, red. K. Maksymiuk, D. Wereda, A. Zawadzki, Siedlce 2016, s. 111-123.

9 M. Andrusiak, op. cit., s. 22-47; Т. Чухліб, Львівський єпископ Йосиф Шумлянський військовий діяч та дипломат Корони Польської (60-ті роки XVII-початок XVIII cm.) [w:] Украӥна: культурна спадщина, наиіональна свідомість, державність, Вип. 21: Scripta manent. Ювілейний збірник на пошану Богдана Якимовича, red. М. Литвин, Львів 2012, s. 788; A. Gi1, I. Skoczylas, Szumlański Jan..., s. 343-350.

10 M. Andrusiak, op. cit., s. 62, 149; Т. Чухліб, op. cit., s. 788-794. 
na Ukrainie i Podolu. W 1675 roku król powierzył Szumlańskiemu administrację jurysdykcji cerkiewnej na terenach odzyskanych po kampaniach wojennych prowadzonych przeciwko Turkom ${ }^{11}$. Jego autorytet miał pomóc w opanowaniu trudnej sytuacji. W 1677 roku Jan III Sobieski nadał Szumlańskiemu prawo do administracji położonych w województwie wołyńskim dóbr monasterów kijowskich (brackiego i Ławry Peczerskiej), a w roku następnym dóbr usytuowanych na obszarze Wielkiego Księstwa Litewskiego, należących do monasteru peczerskiego. Pozyskiwane dochody stanowiły zaplecze materialne Szumlańskiego, ale też świadczyły o dążeniu do uzyskania pozycji w prawosławnych środowiskach Kijowa. Szumlański zaczął tytułować się archimandrytą kijowsko-peczerskim, mimo że tytułu tego używał w tym czasie Innocenty Gizel ${ }^{12}$.

Na skutek nalegań papiestwa Jan III Sobieski zdecydował, że J. Szumlański jako pierwszy władyka prawosławny zadeklarował przystąpienie do unii. W styczniu 1677 roku Szumlański przybył na sejm do Warszawy, a następnie 7 marca potajemnie, w obecności króla, złożył wobec metropolity unickiego Cypriana Żochowskiego katolickie wyznanie wiary. Mimo sugestii Kongregacji Rozkrzewiania Wiary i nuncjusza Martellego Szumlański nie zgodził się na deklarację publiczną. W potwierdzeniu przesłanym papieżowi Innocentemu XI wyjaśniał, że nie mógł jej ogłosić wcześniej z powodu swego oponenta, „wodza schizmatyków” Świstelnickiego, i prosił, aby decyzja ta pozostała niejawna ${ }^{13}$. Utajnienie decyzji wynikało z planów posłużenia się doświadczeniami dyplomatycznymi Szumlańskiego w pertraktacjach prowadzonych z kozaczyzną.

Jan III Sobieski strategię zastosowaną w diecezji lwowskiej wykorzystał w obsadzie prawosławnej eparchii przemyskiej. W celu zapobieżenia konfliktom, jeszcze przed śmiercią prawosławnego władyki przemyskiego Antoniego Winnickiego (26 listopada 1679 r.), król wystawił 19 października 1679 roku przywilej nominacyjny dla jego bratanka Jana Winnickiego, przebywającego wówczas na dworze królewskim „,nadwornego pokojowego” i „husarza gwardii królewskiej”. O wyborze kandydata zdecydowała znajomość ze wspólnych wypraw wojennych. Winnicki od osiemnastego roku życia służył w wojsku Stanisława Jana Jabłonowskiego. Włączenie go do grona najbliższych współpracowników na dworze królewskim może świadczyć o tym, że był dobrym żołnierzem, ale również rokującym politykiem. Król w korespondencji skierowanej do nuncjusza Martellego nominację Winnickiego uzasadniał długotrwałą znajomością i wychowaniem na dworze królewskim. Ojciec przyszłego władyki Stefan był rotmistrzem królewskim. Kandydat na biskupstwo przemyskie pochodził z rodu cieszącego się prestiżem i autorytetem wśród lokalnych elit szlacheckich. Było to kryterium priorytetowe, ponieważ w diecezji przemyskiej (podobnie jak we lwowskiej) praktykowany był zwyczaj elekcji biskupa z udziałem duchowieństwa, przedstawicieli bractw cerkiewnych oraz miejscowej szlachty. Winnicki pomimo młodego wieku (liczył 25 lat) oraz braku przygotowania do stanu

\footnotetext{
1 Архивъ Юго-Западной Россіи [dalej: АЮЗР], сz. 1, t. 10, Кіевь 1904, s. 723-724.

12 АЮЗР, cz. 1, t. 10, s. 736-737; A. Gil, I. Skoczylas, Szumlański Jan ..., s. 345.

13 M. Andrusiak, op. cit., s. 74.
} 
duchownego został wybrany jednomyślnie. Dopiero po wydaniu przez króla przywileju nominacyjnego podjął realizację powinności niezbędnych do konsekracji i na krótki czas wstąpił do klasztoru w Uniowie, gdzie przyjął imię Innocenty ${ }^{14}$. Król nie uległ naciskom nuncjusza, aby odłożyć konsekrację do chwili oficjalnego ogłoszenia przez Winnickiego decyzji o przyjęciu unii. Uwzględniając uwarunkowania polityczne, uważał, że w ówczesnej sytuacji korzystniejsze będzie złożenie tajnego wyznania wiary. Bez powiadomienia nuncjusza wyraził zgodę na konsekrację Winnickiego, która odbyła się 21 listopada 1680 roku w katedrze halickiej w Kryłosie, z udziałem biskupa lwowskiego J. Szumlańskiego i biskupa mukaczewskiego Józefa Wołonyszowskiego (obaj byli tajnymi unitami) ${ }^{15}$.

Działania króla wzbudzały kontrowersje w Stolicy Apostolskiej. Kardynałowie na nadzwyczajnym posiedzeniu Kongregacji Rozkrzewiania Wiary wyrazili wątpliwości w kwestii konsekracji udzielonej przez oficjalnie pozostającego przy prawosławiu Szumlańskiego. W korespondencji skierowanej 23 grudnia 1680 roku do nuncjusza w Warszawie Opizio Pallaviciniego wskazywali na brak doświadczenia Winnickiego, podawali w wątpliwość jego decyzję o przyjęciu unii i wyrażali obawy o umiejętności prowadzenia pracy duszpasterskiej ${ }^{16}$. Nieprzychylne stanowisko Stolicy Apostolskiej może świadczyć o analizie sytuacji tylko w aspekcie religijnym i braku znajomości lokalnych uwarunkowań politycznych i społecznych. 1 stycznia 1681 roku monitorowanie sprawy konsekracji Winnickiego powierzono biskupowi kijowskiemu obrządku łacińskiego Janowi Stanisławowi Witwickiemu ${ }^{17}$. Pomimo udzielonych wyjaśnień Kongregacja Rozkrzewiania Wiary nalegała, aby nie dopuścić do konsekracji biskupiej Winnickiego, i zalecała, aby w tej sprawie wykorzystać pozycję i autorytet prymasa Jana Stefana Wydżgi ${ }^{18}$. Odwoływanie się do autorytetu najwyższych hierarchów świadczy o tym, że z perspektywy Stolicy Apostolskiej niedopuszczenie do konsekracji Winnickiego traktowano jako kwestię najwyższej rangi. W tej sytuacji król kierował się wyborem optymalnej strategii dla państwa i wykazał się suwerennością w podejmowanych decyzjach.

Kolejną inicjatywą Jana III Sobieskiego było zorganizowanie spotkania hierarchów i przedstawicieli społeczności wiernych Cerkwi unickiej i Cerkwi prawosławnej, podczas którego zamierzano doprowadzić do rozstrzygnięcia sporów prawosławno-unickich w Rzeczypospolitej, a zapewne w dalszej perspektywie do unii. $\mathrm{Na}$

14 I. Winnicki, Ustawy rzadu duchownego i inne pisma, do druku przygot. W. Filipo wicz, przedm. S. Stępień, Przemyśl 1998, s. 13-14; Б. Балик, Інокентий Винниикий, епископ Перемиський, Самбірський і Сяноцький (1680-1700), Рим 1978, s. 13-42.

15 I. Winnicki, op. cit., s. 15; Б. Балик, op. cit., s. 93; W. Patjasz, Historyczne znaczenie dzieła biskupa Innocentego Winnickiego [w:] Polska Ukraina 1000 lat sąiedztwa, t. 3: Studia z dziejów greckokatolickiej diecezji przemyskiej, red. S. Stępi eń, Przemyśl 1996, s. 55; M. B endza, Prawosławna diecezja przemyska w latach 1596-1681, Warszawa 1982, s. 213-233.

16 Litterae S.C. Propaganda Fide Eccelesiam Catholicam Ukrainae et Bielarusjae spectantes, collegit et adnotationibus illustravit P. Athanasius, G. Welykyj, vol. 2 (1670-1710), Romae 1955, s. 117-121; Acta Nuntiaturae Polonae [dalej: ANP], t. XXXIV, vol. 1, red. M. Domin, Rzym 1995, s. $107-111$.

17 ANP, t. XXXIV, vol. 1, s. 135-136.

18 Ibidem, s. 166. 
sejmie w 1677 roku została przyjęta konstytucja zwołująca na kolejny sejm, którego obrady zaplanowano na 1678 rok, prawosławnych i unickich hierarchów oraz przełożonych monasterów i przedstawicieli bractw w celu rozpatrzenia wzajemnych pretensji. Spotkanie odłożono prawdopodobnie z obawy przed ingerencją przybyłych na sejm do Grodna, w związku z zaprzysiężeniem przez Jana III Sobieskiego zawartego 17 sierpnia 1678 roku traktatu z Moskwą, posłów rosyjskich Wasyla Buturlina i Iwana Czaadajewa. Obok spraw politycznych dyplomaci rosyjscy planowali przedstawić problem prześladowania wyznawców prawosławia ${ }^{19}$.

Zaplanowane przez króla spotkanie zostało zwołane uniwersałem królewskim z 9 października 1679 roku. Monarcha zaprosił unitów i dyzunitów do Lublina na 24 stycznia 1680 roku, „by z sobą w miłości chrześcijańskiej pełną uczynili rozmowę”. „Colloquium amicibile” nie przyniosło żadnych wiążących decyzji. W Lublinie obecni byli hierarchowie uniccy oraz biskupi lwowski J. Szumlański i przemyski I. Winnicki. Przedstawiciele wyznawców Cerkwi prawosławnej zignorowali zjazd lubelski. Natomiast do króla do Warszawy przybyli delegaci prawosławnego bractwa z Łucka, którzy wyrazili stanowisko prawosławnych, wykazujące, że bez możliwości kontaktu z patriarchami i bez ich udziału nie jest możliwe podjęcie dialogu religijne$\mathrm{go}^{20}$. Przyjęcie tej formy działań przez króla przyczyniło się do sprowadzenia spraw Kościołów wschodnich do praktyki pozaparlamentarnej. Diariusz sejmu z 1681 roku nie wspomina o dyskusji nad tą problematykąa ${ }^{21}$.

Działania króla hierarchowie prawosławni odebrali jako zagrożenie. W obawie przed przymusem przyjęcia unii podjęli poszukiwania wsparcia w Rosji. 10 grudnia 1678 roku do Kijowa przybył, podający się za delegata biskupów prawosławnych: przemyskiego Antoniego Winnickiego i łuckiego Gedeona Czetwertyńskiego, ihumen Preobrażeńskiego monasteru w Lublinie Innocenty Monasterski. Cele poselstwa hierarchowie przedstawili w korespondencji skierowanej do księcia M.A. Golicyna, w której treści skarżyli się na zagrożenia (porównywane do sfory wilków chcących pożreć lub rozproszyć wiernych prawosławnych) i w sytuacji braku możliwości samodzielnej obrony zadeklarowali pragnienie poszukiwania pomocy u cara. Biskup Czetwertyński zwracał się do cara, tytułując jego osobę jako ,jedynego na świecie prawosławnego monarchę i jedynego po Bogu na ziemi, tak jak jedno słońce na niebie". Biskup przemyski A. Winnicki kontakty z Rosją nawiązał już wcześniej. Wiosną 1674 roku w Moskwie przebywał jego wysłannik Stepan Sokalski, który prosił o pomoc w ochronie przed Turkami i skarżył się na „wielki niedostatek” hierarchy i jego otoczenia. W odpowiedzi otrzymał z Moskwy jako prezent skóry soboli o wartości 150 rubli. W połowie lat siedemdziesiątych Winnicki nawiązał korespondencję z rosyjskim rezydentem w Warszawie, diakiem Wasylem Michałowiczem Tiapkinem, z którego wsparciem w marcu 1677 roku Moskwę odwiedził poseł Winnickiego. Biskup ponownie otrzymał upominek w postaci sobolowych skór

19 Б.Н. Флоря, Россия и попытки установления «новой унии» в Речи Посполитой (1678-1681 годbl), „Славяноведение” 2015, № 2, s. 8 .

20 A. Gil, I. Skoczylas, Kościoły wschodnie $w$ państwie polsko-litewskim w procesie przemian $i$ adaptacji. Metropolia kijowska w latach 1458-1795, Lublin 2014, s. 230.

21 M. Wołoszyn, op. cit., s. 251. 
o wartości oszacowanej na 150 rubli $^{22}$. Kontakty zainicjowane przez prawosławnych hierarchów przyczyniły się do stworzenia modelu ingerencji Rosji w sprawy wyznaniowe polsko-litewskiego państwa. W tej sytuacji Sobieski animował inicjatywy wzmacniające postawy prounijne hierarchów obdarzanych zaufaniem, mając świadomość, że zbyt radykalne posunięcia mogą stać się pretekstem do ingerencji Rosji i niechęci kozaczyzny.

Po bezowocnym zjeździe w Lublinie biskupi Szumlański i Winnicki 26 marca 1681 roku w kaplicy zamku królewskiego potajemnie złożyli wyznanie wiary katolickiej, w obecności między innymi upoważnionego przez nuncjusza biskupa kijowskiego Jana Stanisława Witwickiego i delegatów króla, w tym wojewody ruskiego Stanisława Jana Jabłonowskiego. O wydarzeniu następnego dnia powiadomiono papieża Innocentego XI. Biskupi po powrocie do swoich diecezji byli wizytowani przez nuncjusza papieskiego w Warszawie Pallaviciniego ${ }^{23}$. Kongregacja Rozkrzewiania Wiary 3 maja 1681 roku oceniła działania nuncjusza jako godne pochwały papie$\mathrm{ża}^{24}$. Natomiast nuncjusz jako osoby zasługujące na wyróżnienie za zaangażowanie w doprowadzeniu do ogłoszenia decyzji o przyjęciu przez biskupów unii 25 czerwca 1681 roku przedstawił rzymskiej Kongregacji Rozkrzewiania Wiary wojewodę ruskiego S.J. Jabłonowskiego, marszałka nadwornego koronnego Mikołaja Hieronima Sieniawskiego i wojewodę krakowskiego Andrzeja Potockiego ${ }^{25}$. Grono wyróżnionych potwierdza decydujący wpływ na sprawy Kościołów wschodnich w państwie najbliższych współpracowników Sobieskiego. Do upublicznienia decyzji biskupów nie doszło pomimo nacisków nuncjusza skarżącego się, że król wraz z dworem, między innymi S.J. Jabłonowskim, nakłaniali go, iż powinien pobłażliwiej odnosić się do nowych biskupów, ponieważ zachowanie w tajemnicy przyjęcia przez nich unii jest jedynym sposobem na zjednoczenie i przekonanie do idei unii wiernych ${ }^{26}$.

Strategia przyjmowania unii opracowana przez otoczenie dworu królewskiego odbiegała od założeń polityki Stolicy Apostolskiej. Zachowanie elastycznego stanowiska wobec Cerkwi prawosławnej ułatwiało negocjacje na temat pozyskania wojsk kozackich. W świetle oceny nuncjusza Pallaviciniego, przedstawionej 21 kwietnia 1683 roku Kongregacji Rozkrzewiania Wiary, Szumlański i Winnicki byli wewnętrznie przekonani do unii, a późniejsze jej ogłoszenie wynikało z tego, że nie chcieli zrażać Kozaków, którzy mogliby zwrócić się do Rosji, a tym samym narazić na niebezpieczeństwo jej interwencji i wycofania się z wojny z Turkami ${ }^{27}$. Zabiegi o wsparcie militarne Kozaków zyskały szczególnie ważne znaczenie w obliczu wojny z Portą Ottomańską. Król wykorzystał Szumlańskiego w 1682 roku do niezwykle odpowiedzialnego posłannictwa. Władyce lwowskiemu powierzono oddelegowanie mnichów z monasterów prawobrzeżnej Ukrainy do miast lewobrzeżnej Ukrainy. Do ich zadań należało propagowanie wśród Kozaków idei wsparcia króla Sobieskiego

\footnotetext{
22 Б.Н. Флоря, op. cit., s. 5-6.

23 I. Winnicki, op. cit., s. 17; Б. Балик, op. cit., s. 120.

24 ANP, t. XXXIV, vol. 2, red. M. Domin, Rzym 1997, s. 96-97.

25 Ibidem, s. 247-248.

26 Ibidem, s. 16-17.

27 ANP, t. XXXIV, vol. 6, red. M. Domin, Kraków 2008, s. 297-299.
} 
i dostarczenie dokumentów królewskich do wybranych pułkowników, którzy mogliby odpowiedzieć na królewskie rozkazy. Agenci Szumlańskiego mieli odwiedzić Czernihów, Kijów i okolice, Nowogród Siewierski, Perejasław i Połtawęę. W celu pozyskania Kozaków odwoływali się do koncepcji utworzenia autokefalicznej Cerkwi prawosławnej na terytorium Rzeczypospolitej ${ }^{29}$. W memoriale skierowanym do biskupa Szumlańskiego król argumentował: ,„...] starsza wieląset lat Święta Zofia w Kijowie niż Cerkiew Soborna na Moskwie. Czemu by jako władzą duchowną, tak i świecką nie lepiej widzieć w Kijowie, niż tej szukać niewolniczym karkiem w Moskwie". Również w instrukcji dla oddelegowanego z poselstwem do Kozaków Bazylego Iskrzyckiego król stwierdzał: „,...] lepiej mieć głowę i pana w Kijowie [...] albo się go z Krymu, albo ze Stambułu bać spodziewać" ${ }^{30}$. Wsparciem w realizacji tego projektu była królewska nominacja dla Szumlańskiego na kijowsko-peczerską archimandrię po śmierci w 1684 roku archimandryty Innocentego Gizeli. Decyzja ta w aspekcie politycznym była też interpretowana jako komunikat o prawie do Kijowa i planach utworzenia patriarchatu ${ }^{31}$.

Biskup Szumlański na bitwę pod Wiedniem przyprowadził chorągiew pancerną wojsk koronnych liczącą 88 konnych ${ }^{32}$. Obecność biskupa biorącego czynny udział na polu walki (został ranny w lewe ramię) w odsieczy wiedeńskiej umocniła wpływy króla wśród Kozaków ${ }^{33}$. Lekko rannego Szumlańskiego Jan III Sobieski skierował 17 września do Krakowa, gdzie zaplanował jego spotkanie z nuncjuszem. Powracającemu do kraju biskupowi król polecił także niezwłoczny wyjazd na Ukrainę i Wołoszczyznę, zapewne w celu pozyskania Kozaków do prowadzenia wojny przeciw Porcie Ottomańskiej ${ }^{34}$.

Definitywnie plan utworzenia autokefalicznego patriarchatu w Kijowie dla Cerkwi prawosławnej w Rzeczypospolitej załamał się w 1686 roku. W Stambule, w wyniku nie do końca wyjaśnionych okoliczności, prawosławna metropolia kijowska została podporządkowana patriarsze moskiewskiemu, stając się częścią Rosyjskiej Cerkwi Prawosławnej ${ }^{35}$. Dopełnieniem porażki tej idei było umieszczenie w postanowieniach traktatu z Rosją tzw. pokoju Grzymułtowskiego w dziewiątym punkcie

28 К.А. Кочегаров, Речь Посполитая и Россия в 1680-1686 года. Заключение договора о Вечном мире 1686 г., Москва 2008, s. 110-111. Tłumaczenie na język polski: K. Koczegarow, Rzeczpospolita a Rosja w latach 1680-1686. Zawarcie traktatu o pokoju wieczystym, red. nauk. T. Szwaciński, Warszawa 2017.

29 Litterae Nuntiorum Apostolicorum historiam Ucrainae illustrantes..., s. 314-31; M. Bendza, Tendencje unijne względem Cerkwi prawostawnej w Rzeczypospolitej w latach 1674-1686, Warszawa 1987, s. 185.

30 Cyt. za: Z. Wójcik, Jan Sobieski, Warszawa 1983, s. 306; J. Wołoszyn, op. cit., s. 253.

31 К.А. Кочегаров, Речь Посполитая и Россия..., s. 206.

32 J. Wimmer, Wiedeń 1683. Dzieje kampanii i bitwy, Warszawa 1983, s. 224.

33 M. Andrusiak, op. cit., s. 22-23, 168.

34 Maria Kazimiera i Jan Sobiescy. Listy okresu odsieczy wiedeńskiej, oprac. L. Kukulski, Warszawa 1983, s. 157.

35 M. Bendza, Inkorporacja metropolii kijowskiej do patriarchatu moskiewskiego [w:] Autokefalie Kościoła prawosławnego w Polsce, red. A. Mironowicz, U. Pawluczuk, P. Chomik, Białystok 2006, s. 65-114. 
klauzuli umożliwiającej Rosji ochronę prawosławnych w państwie polsko-litewskim $^{36}$. Analiza przebiegu rokowań wskazuje na to, że posłowie oddelegowani do negocjacji pokojowych z Rosjanami nie byli przygotowani do pertraktacji problematyki wyznaniowej. Natomiast w dyplomacji rosyjskiej zainteresowanie sprawami religijnymi w Rzeczypospolitej odnotowuje się od połowy XVII wieku ${ }^{37}$. W projekcie pokoju wieczystego umieszczono zapis o budowie kościołów obrządku łacińskiego w Kijowie i Smoleńsku, ale intrygi patriarchy Joachima, jednej z najbardziej wpływowych osób w życiu politycznym Rosji, doprowadziły do usunięcia zapisu tego zobowiązania. Członek delegacji z Wielkiego Księstwa Litewskiego Marcjan Aleksander Ogiński poinformował nawet nuncjusza o pomyślnym przebiegu rokowań, których efektem będzie wyznaczenie miejsc kultu dla społeczności Kościoła łacińskiego w Smoleńsku i Kijowie ${ }^{38}$. Być może Rzeczpospolita, akceptując zapis punktu dziewiątego traktatu Grzymułtowskiego, przede wszystkim brała pod uwagę zobowiązania Rosji wobec katolików i unitów w granicach państwa rosyjskiego, zakładając zanik w Rzeczypospolitej Cerkwi prawosławnej w swej zorganizowanej formie ${ }^{39}$. Pokój wieczysty dawał teoretyczne gwarancje zachowania równowagi religijnej w stosunkach Rzeczypospolitej z Rosją, rządzoną wówczas przez niezainteresowaną eskalowaniem konfliktu z państwem polsko-litewskim regentkę Zofię Aleksiejewną Romanową ${ }^{40}$. Jednak badania historyków rosyjskich wskazują, że opcja wojny przeciwko Rzeczypospolitej w latach osiemdziesiątych XVII wieku miała wielu zwolenników wśród członków Dumy Bojarskiej. Rosja natychmiast podjęła praktyczne działania zmierzające do skutecznej kontroli prawosławnych na obszarze pozostałej w Rzeczypospolitej części metropolii kijowskiej. Rosyjscy posłowie na czele z Borysem Szeremietiewem, oddelegowani do Lwowa w celu przyjęcia przysięgi króla Jana III Sobieskiego na zakończenie pertraktacji o wieczystym pokoju i antyosmańskim przymierzu zostali zobowiązani do rozdawania ulotek informujących o dziewiątym punkcie warunków pokoju ${ }^{41}$. Posłowie rosyjscy Borys Szeremietiew i Iwan Czapajew w trakcie ratyfikacji domagali się, aby z tytułów hierarchów cerkiewnych

36 VL, t. VI, Petersburg 1860, s. 146-164.

37 Zainicjował je patriarcha Nikon, który dostrzegł możliwość wzmocnienia wpływów Rosji za zachodnią jej granicą poprzez odpowiedni wpływ na Cerkiew prawosławną, co poświadczała intensyfikacja kontaktów dyplomatycznych. W 1653 r. do Rzeczypospolitej zostali oddelegowani trzej posłowie: Borys Repnin, Bogdan Chitrowo, Ałma Iwanowicz. Zgodnie z otrzymaną instrukcją mieli wspomnieć o skargach wnoszonych przez prawosławnych. Z podobnymi roszczeniami przystąpili do rokowań pokojowych posłowie moskiewscy w $1656 \mathrm{r}$. Zgodnie z udzieloną im w Moskwie instrukcją mieli upomnieć się o sprawy prawosławnych mieszkańców Rzeczypospolitej ze szczególnym uwzględnieniem prawa biskupów prawosławnych do wyjazdu po chirotonię do patriarchy konstantynopolitańskiego. L. Ćwikła, Polityka władz państwowych wobec Kościoła prawosławnego i ludności prawosławnej w Królestwie Polskim, Wielkim Księstwie Litewskim oraz Rzeczypospolitej Obojga Narodów w latach 1344-1795, Lublin 2006, s. 241-243.

38 К.А. Кочегаров, Речь Посполитая и Россия..., s. 353.

39 A. Mironowicz, Prawostawie i unia za panowania Jana Kazimierza, Białystok 1997, s. 263.

40 A. Gil, I. Skoczylas, Kościoły wschodnie..., s. 322.

41 К.А. Кочегаров, Князья Огинские и сношения православных Великого княжества Литовского с Россией в 80-х гг. ХVII в. [w:] Россия, Польша, Германия в европейской и мировой политике, Москва 2009, s. 104. 
usunięto tytulaturę odnoszącą się do ziem, na których panowanie Rosji potwierdzone zostało w pokoju Grzymułtowskiego ${ }^{42}$. Analiza tytulatury w dokumentach wystawionych w latach późniejszych wykazuje, że zarówno hierarchia, jak i król nie dostosowali się do żądań dyplomacji rosyjskiej. Szumlański nadal posługiwał się tytułem administratora metropolii kijowskiej i archimandryty peczerskiego (np. w przywileju królewskim z 1694 r., nadającym mu prawo administracji diecezją łucką) ${ }^{43}$.

Jan III Sobieski był świadomy niebezpieczeństw kryjących się w upolitycznieniu przez Rosję problematyki religijnej. W tej sytuacji król podjął działania ukierunkowane na zapewnienie pokoju wyznaniowego przez zwiększenie konfesyjnej homogeniczności społeczeństwa poprzez przekonanie do unii eparchii prawosławnych. W pozostającej przy prawosławiu diecezji łuckiej Sobieski realizował sprawdzoną strategię kreowania do godności biskupiej osób z grona zaufanych stronników. Po opuszczeniu katedry w Łucku przez Gedeona Czetwertyńskiego, który udał się do Moskwy, gdzie w 1685 roku przyjął od patriarchy Joachima godność metropolity (wraz ze zmienionym tytułem „,metropolita kijowski i halicki i Małej Rosji”) ${ }^{44}$, król z protekcji biskupa Szumlańskiego na katedrze w Łucku osadził jego brata Aleksandra Atanazego, a po jego śmierci wydał w 1694 roku przywilej powierzający administrowanie eparchią łucką J. Szumlańskiemu ${ }^{45}$ do czasu nominacji Dionizego Żabokrzyckiego (12 maja 1695 r. $)^{46}$. Biskup łucki posiadał znaczącą pozycję w życiu publicznym i cieszył się uznaniem lokalnych środowisk szlacheckich. Piastował urzędy sędziego sądu kapturowego województwa wołyńskiego, podwojewody, podstarosty krzemienieckiego, pisarza ziemskiego, był marszałkiem sejmiku ziemi wołyńskiej i posłem na sejm z województw: wołyńskiego (1674 r.), kijowskiego (1678/1679 r.), bracławskiego (1688 r. $)^{47}$. Zasługi i lojalność Żabokrzyckiego dla Rzeczypospolitej król oceniał bardzo wysoko i często wzywał go jako doradcę do Warszawy na rady senatorskie. Na Wołyniu wykorzystywał jego autorytet pozyskany $\mathrm{w}$ trakcie poselstw z województwa i posiedzeń sądów trybunalskich ${ }^{48}$. Król oczekiwał dalszej współpracy z Żabokrzyckim po objęciu biskupstwa ${ }^{49}$.

42 К.А. Кочегаров, Речь Посполитая и Россия..., s. 453.

$43 A Ю P$, cz. 1, t. 10, s. 380.

44 W. Mokry, Stosunek państwowych i cerkiewnych władz moskiewskich do ukraińskiej Cerkwi prawostawnej i unickiej w wiekach XVII-XX [w:] Unia brzeska. Geneza, dzieje i konsekwencje w kulturze narodów słowiańskich, red. R. Łużny, F. Ziejka, A. Kępiński, Kraków 1994, s. 85.

45 AЮP, cz. 1, t. 10, s. 380-381; M. Andrusiak, op. cit., s. 108.

46 С.В. Курганов ичъ, Діонісій Жабокриџький, єпископь Луцьькій и Острожскій. Историкобіографическій очеркъ, Кіевъ 1914, s. 285-287.

47 Ibidem, s. 27, 38; J. Stolicki, Wobec wolności i króla. Działalność polityczna szlachty ruskiej, ukrainnej $i$ wotyńskiej w latach 1673-1683, Kraków 2007, s. 91, 273, 299, 300; R. Kołodziej, „Ostatni wolności naszej klejnot”. Sejm Rzeczypospolitej za panowania Jana III Sobieskiego, Poznań 2014, s. $513,546$.

48 Ф.І. Титовъ, Западная Русь в борьбе за веру и народность в XVII-XVIII в.в. (1654-1725), t. 1, Кіевъ 1905, s. 185.

$49, \ldots[\ldots]$ jak się wielce cieszymy z odmiany stanu wierności waszej in perfectiorem existentiam, tak bynajmniej nie wątpimy, że strój świecki odmieniwszy, nie wyzułeś się ex innato do przysługi ku dobru pospolitemu zelo ac studio i że tąż ochotą i życzliwością do wszystkich publicznych obrad concurrere nie 
Jan III Sobieski podejmował rozważne decyzje przy nominacji biskupów diecezji obsadzonych przez unitów. Wstępujący w 1693 roku na katedrę chełmską Gedeon Orański pochodził ze środowiska wojskowych, o czym często wspominał: ,ja od buzdyganu wstąpiłem, to jest na świecie porucznikiem będąc". O wyborze tego kandydata zdecydowały również koligacje rodzinne z unickim biskupem włodzimierskim Benedyktem Glińskim ${ }^{50}$. Objęcie godności biskupiej król prawdopodobnie zaplanował dla swego krewnego Antonina Żółkiewskiego. Polecony szczególnej uwadze i opiece Kongregacji Rozkrzewiania Wiary przez metropolitę Cypriana Żochowskiego Żółkiewski w 1690 roku podjął studia w rzymskim Kolegium Urbanum $^{51}$. Po powrocie do kraju w 1697 roku objął unicką diecezję pińską. Przywileje nominacyjne dla pozostałych diecezji król wydał dla wykształconych w rzymskich kolegiach bazylianów, między innymi Augustyna Łodziaty (diecezja chełmska) i Leona Załęskiego (metropolia kijowska). Sobieski w doborze hierarchów kierował się głównie celami politycznymi i racją stanu Rzeczypospolitej. Król świadomie nominował osoby wzbudzające zaufanie w środowiskach kozackich, ale doświadczonych urzędników i żołnierzy cieszących się autorytetem wśród lokalnych elit szlacheckich. W działalności hierarchów wywodzących się ze środowisk wojskowych nie zauważa się zaniedbań duszpasterskich.

Nie we wszystkich diecezjach przyjęta przez Sobieskiego strategia przyniosła rezultaty. Król nie zdołał doprowadzić do nominacji biskupa prawosławnej eparchii białoruskiej (mohylewsko-mścisławskiej). Elekci odmawiali przejścia na unię. Eparchą białoruskim Serapion Polchowski został dopiero w roku 1697.

Założeniem polityki wyznaniowej Sobieskiego było doprowadzenie do zmian postaw religijnych drogą utożsamiania się z interesem państwa. Unicki metropolita kijowski C. Żochowski w korespondencji skierowanej w lutym 1679 roku do Kongregacji Rozkrzewiania Wiary zauważył, że życzeniem króla jest, aby prawosławni uznali władzę papieża nie tylko z powodów religijnych, ale przede wszystkim ze względu na rację stanu państwa, w którego interesie jest odcięcie prawosławnych mieszkańców Rzeczypospolitej od jurysdykcji patriarchy Konstantynopola i od cara rosyjskiego ${ }^{52}$. Strategia zastosowana przez Sobieskiego i współpracujących z nim hierarchów nie burzyła więzi społecznych, lecz przyczyniała się do tworzenia nowych elementów tożsamości mieszkańców ziem ruskich. O recepcji idei budowania wielowyznaniowej i wieloetnicznej wspólnoty pod panowaniem jednego monarchy w szerokich kręgach społecznych świadczą powstałe na przełomie XVII i XVIII stulecia dzieła malarstwa ikonowego, w których kompozycji umieszczono Jana III Sobieskiego z Marią Kazimierą. W dziejach malarstwa ikonowego żaden z monarchów państwa polsko-litewskiego nie stał się bohaterem tak często zidentyfikowanym na

omieszkasz, którąś w przeszłym swoim stanie chwalebnie oświadczał [...]” (6 września 1695 r.). AЮP, cz. 1, t. IV, Кіевъ 1871, s. 110.

50 Archiwum Państwowe w Lublinie, Chełmski Konsystorz Grecko-Katolicki, sygn. 680, s. 4-5.

${ }^{51}$ Epistolae metropolitarum Kioviensium catholicorum Cypriani Zochovskyj, Leonis Slubicz Zalenskyj, Georgii Vynnyckyj, vol. 3 (1674-1713), collegit, paravit, adnotavit editionemque curavit P. Athanasius, G. Welykyj, Romae 1956, s. 135-138.

52 Ibidem, s. 51-55. 
ikonach ${ }^{53}$. Jest to świadectwo kultury materialnej wyrażające popularność króla oraz uznania jego osoby przez współczesnych za bohatera godnego zachowania w pamięci pokoleń. Ta forma wizualizacji była czytelna i zrozumiała w szerokich kręgach odbiorców.

Doświadczenia wojenne wpływały na przeobrażenia postaw prawosławnych mieszkańców ziem ruskich Rzeczypospolitej. Sprzyjające okoliczności doprowadziły do podjęcia przez biskupa przemyskiego Innocentego Winnickiego decyzji o publicznym wyznaniu wiary, które złożył 23 czerwca 1691 roku w warszawskiej katedrze św. Jana Chrzciciela w obecności Jana III Sobieskiego. Król poprosił biskupa o odprawienie w kaplicy królewskiej uroczystej liturgii w obrządku greckim z okazji przypadających w następnym dniu jego imienin. Winnicki podczas spotkania z nuncjuszem Andreą Santacrocem, w obecności przedstawicieli szlachty swojej diecezji stwierdził, że zawsze czuł się unitą, a decyzję o ogłoszeniu unii odkładał z woli kró$1 \mathrm{a}^{54}$. Ogłoszenie przyjęcia unii przez Winnickiego zostało przychylnie przyjęte przez lokalne elity szlacheckie ${ }^{55}$.

Król nie nalegał na publiczne ogłoszenie decyzji o przystąpieniu do unii przez biskupa lwowskiego. Szumlański nadal pertraktował w sprawach Rzeczypospolitej, między innymi z hetmanem Iwanem Mazepą, za co żądano dla niego w Moskwie kary śmierci ${ }^{56}$. Był też brany pod uwagę jako kandydat do obsady kijowskiej metropolii prawosławnej, w przypadku przejścia wojska zaporoskiego pod zwierzchnictwo Sobieskiego ${ }^{57}$. Wstrzymywanie decyzji o publicznej deklaracji przystąpienia do unii Szumlańskiego było uwarunkowane także planami króla wobec Mołdawii. Sobieski w wyprawach mołdawskich uwzględniał ich kontekst religijny. Ważną rolę w gronie stronników króla Sobieskiego odgrywał, wspierający politykę hospodara Ştefana Petryczejki, metropolita mołdawski Dosoftei (Dozydeusz). Po konflikcie z nadzorowanym przez urzędników sułtańskich patriarchatem konstantynopolitańskim opuścił w 1684 roku Mołdawię wraz z wojskami króla Sobieskiego, zabierając ze sobą tzw. skarb kościelny: cenne szaty, naczynia i księgi liturgiczne, dokumenty oraz relikwie św. Jana Nowego (Suczawskiego) ${ }^{58}$. Po czasowym złożeniu w Stryju w 1691

53 Postać Sobieskiego wraz z żoną Marią Kazimierą oraz biskupem lwowskim J. Szumlańskim została zidentyfikowana m.in. w popularnej i charakterystycznej dla Rusi ikonie typu Matki Boskiej Opieki (znanej jako Pokrow) (Muzeum Narodowe w Krakowie, sygn. MNK-XVIII-47) oraz na dwóch ikonach prawdopodobnie z końca XVII wieku pochodzących z cerkwi w Gorajcu. Jedną z nich umieszczono w królewskim rzędzie ikonostasu, podczas gdy druga prawdopodobnie miała być eksponowana wewnątrz świątyni. Postać króla Sobieskiego została zidentyfikowana również w ikonie Podwyższenie Krzyża Świętego ze Sytychowa (ukr. Сытыхов) koło Lwowa (Muzeum Narodowe we Lwowie) oraz w ikonie z Wojkowej, znajdującej się w zbiorach Muzeum Okręgowego w Nowym Sączu. M.P. Kruk, Jan III Sobieski i Maria Kazimiera na ikonach, http://mobile.wilanow-palac.pl/article/jan iii sobieski i maria kazimiera na ikonach.html, dostęp 21 kwietnia $2018 \mathrm{r}$.

54 I. Winnicki, op. cit., s. 22-23; Б. Балик, op. cit., s. 191-193.

55 J.W. Wołoszyn, op. cit., s. 255.

56 Encyklopedia kościelna, wyd. M. Nowodworski, t. 28, Warszawa 1905, s. 75.

57 Т. Чухліб, ор. cit., s. 791-798.

58 K. Górecka, Św. Jan Nowy Suczawski. Postać, dzieje relikwii, kult i ikonografia Świętego, ASP w Warszawie mps 7806, Warszawa 2006, s. 21-25. 
roku relikwie męczennika zostały zdeponowane na zamku królewskim w Żółkwi, a w 1692 powierzono je zakonowi bazylianów przy żółkiewskiej cerkwi pw. Narodzenia Chrystusa Pana. Obecność relikwii dodawała splendoru królewskiej siedzibie, przyciągała wielu pielgrzymów, a składane ofiary przyśpieszyły wzniesienie nowego gmachu cerkwi. Cieszący się względami Jana III Sobieskiego metropolita Dosoftei zamieszkał w Żółkwi, gdzie zmarł 13 grudnia 1693 roku. Po ceremonii pogrzebowej, uświetnionej mową wygłoszoną przez biskupa lwowskiego J. Szumlańskiego, pochowany został w tamtejszej cerkwi bazyliańskiej ${ }^{59}$. Zwierzchnictwo nad obszarem Wołoszczyzny w granicach Rzeczypospolitej, podlegającym dotychczas jurysdykcji duchowej metropolity Dozydeusza, w 1694 roku Sobieski przekazał Szumlańskiemu. W uzasadnieniu król odwoływał się do zasług hierarchy dla kraju i na polu duszpasterskim $^{60}$. Nie można wykluczyć, że decyzja króla wynikała z planów rozszerzenia unii na obszarach Mołdawii ${ }^{61}$. Prawdopodobnie z akceptacją króla Szumlański podtrzymywał okazjonalne kontakty z patriarchatem moskiewskim. 29 listopada 1693 roku do patriarchy moskiewskiego Adriana wystosował list $\mathrm{z}$ gratulacjami z okazji wstąpienia na perestoł patriarchalny i z prośbą o błogosławieństwo dla siebie i brata, biskupa łuckiego Atanazego ${ }^{62}$.

Po przeorientowaniu polityki zagranicznej w roku 1692 celowość działań Szumlańskiego jako hierarchy prawosławnego straciła znaczenie. W tej sytuacji król 6 grudnia 1694 roku w reskrypcie skierowanym do Szumlańskiego wzywał do zwołania we Lwowie synodu unijnego. Uczestnikom obrad wydał gwarancje bezpieczeństwa $^{63}$. Pomimo nalegań Szumlańskiego, apelującego do nieprzekonanych do unii środowisk mieszczan, bractw i zakonników o zachowanie wierności królowi i rozwagę w sytuacji mogącej doprowadzić do pozostania prawosławnych bez hierarchii cerkiewnej, synod nie przyniósł oczekiwanych rezultatów ${ }^{64}$. Decyzję o przystąpieniu do unii diecezji lwowskiej odłożono. Król i biskup postanowili nie zastosować środków przymusu i unikali atmosfery konfliktu.

Szumlański przystąpienie do unii diecezji lwowskiej ogłosił dopiero po śmierci Jana III Sobieskiego. 14 kwietnia 1700 roku zwołał w katedrze św. Jura sobór duchowieństwa diecezji lwowskiej, podczas którego podjęto decyzję o wyjeździe biskupa do Warszawy w celu ogłoszenia deklaracji o przystąpieniu do unii ${ }^{65}$. Szumlański

59 T. Mańkowski, Mecenat Jana III Sobieskiego w Żótkwi, Kraków 1948, s. 19; S. Barącz, Pamiątki miasta Żótkwi, Lwów 1877, s. 41, 48, 63.

${ }_{60}$, ,...] iż w osobliwym respekcie mając znamienite zasługi wielebnego Józefa Szumlańskiego, lwowskiego, halickiego i podolskiego władyki, któremi tak w cerkwi Bożej przez nieustające około dusz sobie powierzonych pieczołowicie, jako też i ojczyźnie, przez wierną i życzliwą w każdych okazjach przysługę osobliwie się zalecił". AЮP, cz. 1, t. 10, s. 378-379.

${ }_{61}$ J. Pietrzak, Metropolita, święte relikwie i skarby. Jeszcze raz o pobycie wladyki mołdawskiego Dozyteusza w Polsce w latach 1686-1693 i kwestii spadku po nim [w:] Conferinţa ştiinţifică internaţională: Dialectica necesităţii şsi libertății în educaţie, col. red. V. Contantinov, Chişinău 2016, s. 213-225.

62 AЮP, cz. 1, t. 10, s. 793-795.

63 Ibidem, s. 796-797.

${ }_{64}$ E. Likowski, Dzieje Kościoła unickiego na Litwie i Rusi w XVIII i XIX w. uważane głównie ze względu na przyczyny jego upadku, t. 2, Warszawa 1906, s. 263-268.

65 M. Andrusiak, op. cit., s. 117. 
katolickie wyznanie wiary złożył na ręce prymasa, w obecności króla Augusta II, nuncjusza Jana Antoniego Davii, senatu i licznie zgromadzonej szlachty. Ceremonia odbyła się 6 czerwca 1700 roku w warszawskim kościele kapucynów, miejscu czasowego pochówku króla Jana III Sobieskiego do czasu uroczystej ceremonii pogrzebowej w Krakowie (nastąpiła dopiero w 1734 r.) ${ }^{66}$.

Kluczowym elementem taktyki Sobieskiego wobec Kościołów wschodnich była polityka doboru kandydatów do obsady diecezji. Wybór osób wywodzących się ze środowisk wojskowych i dworskich znanych królowi ze wspólnych kampanii wojennych gwarantował realizację planów politycznych wymagających często wybiegów, ale i gwarancji wierności państwu, i pozwalał uniknąc promowania osób ze środowisk podejmujących współpracę z Rosją. Powierzanie władzy w diecezjach osobom bez formacji teologicznej i duchownej mogło też sprzyjać ambiwalencji postaw i poglądów religijnych. Strategia ta stwarzała możliwości współpracy z Kozakami i stanowiła ochronę przed ingerencją Rosji. Nabrała szczególnego znaczenia po podpisaniu tzw. traktatu Grzymułtowskiego, którego dziewiąty punkt stwarzał możliwości interwencji Rosji w sprawach Cerkwi prawosławnej. Rozszerzanie unii poprzez obsadę diecezji przez zaufanych kandydatów zdecydowało o tym, że przywileje prawosławnych nie zostały formalnie uszczuplone. Był to wybór optymalnej strategii politycznej i społecznej.

Konsekwencją polityki Jana III Sobieskiego było rozszerzenie katolickiej metropolii kijowskiej obrządku wschodniego (zjednoczonej z Rzymem) o diecezje lwowską, przemyską, łucką oraz parafie arcybiskupstwa metropolitarnego (kijowskiego) z województw kijowskiego i częściowo bracławskiego. Zasięg zmian na mapie wyznaniowej był znaczący. W świetle szacunków Ludomira Bieńkowskiego w latach sześćdziesiątych XVII wieku parafie prawosławne stanowiły około dwóch trzecich lub trzech czwartych ogólnej liczby parafii Kościołów wschodnich. W XVIII wieku liczba parafii prawosławnych w diecezji mohylewskiej oraz kijowskiej na obszarze Rzeczypospolitej sięgała około 500, co stanowiło około 5\% ogółu parafii Kościołów wschodnich $^{67}$. Dokonania Sobieskiego wobec Kościołów wschodnich doprowadziły do zakończenia ponad stuletniego procesu dezorganizacji struktur. Stabilizacja organizacyjna stała się gruntem umożliwiającym zapoczątkowanie „złotej doby” Cerkwi unickiej w granicach państwa polsko-litewskiego, tworząc kulturową jedność Slavia Unita. Jej politycznym rezultatem było pełniejsze utożsamianie się społeczności Cerkwi katolickiej obrządku greckiego z kulturą i społeczną strukturą sarmackiej Rzeczypospolitej ${ }^{68}$.

Działania króla Jana III Sobieskiego wobec Kościołów wschodnich prowadziły do integracji polityczno-społecznej państwa polsko-litewskiego i wpisywały się w procesy konfesjonalizacji w epoce nowożytnej ${ }^{69}$.

${ }^{66}$ Fundacja zakonu i kościoła księży kapucynów w Warszawie opisana przez Michała Balińskiego, Warszawa 1840.

67 L. Bieńkowski, op. cit., s. 851-852.

68 A. Gil, I. Skoczylas, Kościoły wschodnie..., s. 233.

69 H. Schilling, Konfesjonalizacja. Kościót i państwo w Europie doby przednowoczesnej, thum. J. Kałążny, posł. H. Orłowski, Poznań 2010, passim. 


\section{BIBLIOGRAFIA}

\section{Źródła rękopiśmienne}

Archiwum Państwowe w Lublinie, Chełmski Konsystorz Grecko-Katolicki, sygn. 680.

\section{Źródła drukowane}

Acta Nuntiaturae Polonae, t. XXXIV, vol. 1, red. M. Domin, Rzym 1995; vol. 2, Rzym 1997; vol. 6, Kraków 2008.

Epistolae metropolitarum Kioviensium catholicorum Cypriani Zochovskyj, Leonis Slubicz Zalenskyj, Georgii Vynnyckyj, vol. 3 (1674-1713), collegit, paravit, adnotavit editionemque curavit P. Athanasius, G. Welykyj, Romae 1956.

Litterae Nuntiorum Apostolicorum historiam Ucrainae illustrantes (1550-1850), vol. 12 (1670-1674), collegit, paravit, adnotavit editionemque curavit P. Athanasius, G. Welykyj, Romae 1968.

Litterae S.C. Propaganda Fide Eccelesiam Catholicam Ukrainae et Bielarusjae spectantes, vol. 2 (1670-1710), collegit et adnotationibus illustravit P. Athanasius, G. Welykyj, Romae 1955.

Maria Kazimiera i Jan Sobiescy. Listy okresu odsieczy wiedeńskiej, oprac. L. Kukulski, Warszawa 1983.

Volumina Legum, wyd. J. Ohryzko, t. V, VI, Sankt Petersburg 1860.

Winnicki I., Ustawy rzadu duchownego i inne pisma, do druku przygot. W. Filipowicz, przedm. S. Stępień, Przemyśl 1998.

Архивъ Юго-Западной Россіи, сz. 1, t. 4, Кіевъ 1871; t. 10, Кіевъ 1904.

\section{Literatura}

Andrusiak M., Józef Szumlański. Pierwszy biskup unicki lwowski (1667-1708), Lwów 1934.

Barącz S., Pamiątki miasta Żółkwi, Lwów 1877.

Bendza M., Inkorporacja metropolii kijowskiej do patriarchatu moskiewskiego [w:] Autokefalie Kościoła prawosławnego w Polsce, red. A. Mironowicz, U. Pawluczuk, P. Chomik, Białystok 2006, s. 65-114.

Bendza M., Prawosławna diecezja przemyska w latach 1596-1681, Warszawa 1982.

Bendza M., Tendencje unijne względem Cerkwi prawosławnej w Rzeczypospolitej w latach 1674-1686, Warszawa 1987.

Bieńkowski L., Organizacja Kościoła wschodniego w Polsce [w:] Kościół w Polsce, t. 2, red. J. Kłoczowski, Kraków 1968, s. 781-1049. 
Ćwikła L., Polityka władz państwowych wobec Kościoła prawosławnego i ludności prawosławnej w Królestwie Polskim, Wielkim Księstwie Litewskim oraz Rzeczypospolitej Obojga Narodów w latach 1344-1795, Lublin 2006.

Encyklopedia kościelna, wyd. M. Nowodworski, t. 28, Warszawa 1905.

Fundacja zakonu i kościoła księży kapucynów w Warszawie opisana przez Michała Balińskiego, Warszawa 1840.

Gil A., Skoczylas I., Kościoły wschodnie w państwie polsko-litewskim w procesie przemian i adaptacji. Metropolia kijowska w latach 1458-1795, Lublin 2014.

Gil A., Skoczylas I., Szumlański Jan (Iwan) w zakonie Józef [w:] Polski słownik biograficz$n y$, t. XLIX, Warszawa-Kraków 2012, s. 343-350.

Górecka K., Św. Jan Nowy Suczawski. Postać, dzieje relikwii, kult i ikonografia Świętego, ASP w Warszawie mps 7806, Warszawa 2006.

Koczegarow K., Rzeczpospolita a Rosja w latach 1680-1686. Zawarcie traktatu o pokoju wieczystym, red. nauk. T. Szwaciński, Warszawa 2017.

Kołodziej R., „Ostatni wolności naszej klejnot”. Sejm Rzeczypospolitej za panowania Jana III Sobieskiego, Poznań 2014.

Kruk M.P., Jan III Sobieski i Maria Kazimiera na ikonach, http://mobile.wilanow-palac.pl/ article/jan_iii_sobieski_i_maria_kazimiera_na_ikonach.html, dostęp $21 \mathrm{kwietnia} 2018 \mathrm{r}$.

Likowski E., Dzieje Kościoła unickiego na Litwie i Rusi w XVIII i XIX w. uważane głównie ze względu na przyczyny jego upadku, t. 2, Warszawa 1906.

Mańkowski T., Mecenat Jana III Sobieskiego w Żółkwi, Kraków 1948.

Mironowicz A., Działalność nuncjusza Franciszka Martellego w Rzeczypospolitej w latach 1675-1681 [w:] Nuncjatura Apostolska w Rzeczypospolitej, red. T. Chynczewska-Hennel, K. Wiszowata-Walczak, Białystok 2012, s. 321-335.

Mironowicz A., Kościót prawosławny w dziejach dawnej Rzeczypospolitej, Białystok 2001.

Mironowicz A., Prawosławie i unia za panowania Jana Kazimierza, Białystok 1997.

Mokry W., Stosunek państwowych i cerkiewnych władz moskiewskich do ukraińskiej Cerkwi prawostawnej i unickiej w wiekach XVII-XX [w:] Unia brzeska. Geneza, dzieje i konsekwencje w kulturze narodów stowiańskich, red. R. Łużny, F. Ziejka, A. Kępiński, Kraków 1994, s. 83-94.

Patjasz W., Historyczne znaczenie dzieła biskupa Innocentego Winnickiego [w:] Polska Ukraina 1000 lat sąsiedztwa, t. 3: Studia z dziejów greckokatolickiej diecezji przemyskiej, red. S. Stępień, Przemyśl 1996, s. 51-62.

Pietrzak J., Metropolita, święte relikwie i skarby. Jeszcze raz o pobycie władyki mołdawskiego Dozyteusza w Polsce w latach 1686-1693 i kwestii spadku po nim [w:] Conferinţa ştiinţifică internaţională: Dialectica necesităţii şi libertăţii în educaţie, col. red. V. Contantinov, Chişinău 2016, s. 213-225.

Schilling H., Konfesjonalizacja. Kościót i państwo w Europie doby przednowoczesnej, tłum. J. Kałążny, posł. H. Orłowski, Poznań 2010.

Stolicki J., Wobec wolności i króla. Działalność polityczna szlachty ruskiej, ukrainnej i wotyńskiej w latach 1673-1683, Kraków 2007.

Wawrzeniuk P., Confessional civilising in Ukraine: the bishop Iosyf Shumliansky and the introduction of reforms in the diocese of Lviv 1668-1708, [Stockholm] 2005.

Wereda D., Polityka Jana III Sobieskiego wobec hierarchów cerkiewnych [w:] Spoleczeństwo polskie $i$ wojsko. Studia i materiaty, red. K. Maksymiuk, D. Wereda, A. Zawadzki, Siedlce 2016, s. 111-123.

Wimmer J., Wiedeń 1683. Dzieje kampanii i bitwy, Warszawa 1983. 
Wołoszyn J., Problematyka wyznaniowa w praktyce parlamentarnej Rzeczypospolitej w latach 1648-1696, Warszawa 2003.

Wójcik Z., Jan Sobieski, Warszawa 1983.

Балик Б., Інокентий Винницкий, епископ Перемиський, Самбірський $і$ Сяноцький (1680-1700), Рим 1978.

Кочегаров К.А., Князья Огинские и сношения православных Великого княжества Литовского с Россией в 80-х гг. ХVII в. [w:] Россия, Польша, Германия в европейской и мировой политике, Москва 2009, s. 82-117.

Кочегаров К.А., Речь Посполитая и Россия в 1680-1686 года. Заключение договора о Вечном мире 1686 г., Москва 2008.

Кургановичъ С.В., Діонісій Жабокрицький, єпископь Луиькій и Острожскій. Историко-біографическій очеркъ, Кіевъ 1914.

Титовъ Ф.I., Западная Русь в борьбе за веру и народность в XVII-XVIII в.в. (16541725), t. 1, Кіевъ 1905.

Флоря Б.Н., Россия и попытки установления «новой унии» в Речи Посполитой (16781681 годы), „Славяноведение” 2015, № 2, s. 3-18.

Чухліб Т., Львівський єпископ Йосиф Шумлянський - військовий діяч та дипломат Корони Польської (60-ті роки XVII-початок XVIII cm.) [w:] Україна: культурна спадщина, національна свідомість, державність, Вип. 21: Scripta тапепt. Ювілейний збірник на пошану Богдана Якимовича, red. М. Литвин, Львів 2012, s. 787-801. 